\title{
BIOFILM AND CAPSULE FORMATION OF THE DIATOM ACHNANTHIDIUM MINUTISSIMUM ARE AFFECTED BY A BACTERIUM ${ }^{1}$
}

\author{
Miriam Windler, ${ }^{2,3}$ Katrin Leinweber, ${ }^{3}$ Carolina Rio Bartulos \\ Department of Biology, University of Konstanz, Konstanz 78457, Germany \\ Bodo Philipp \\ Institute of Molecular Microbiology and Biotechnology, Münster 48149, Germany \\ and Peter G. Kroth \\ Department of Biology, University of Konstanz, Konstanz 78457, Germany
}

\begin{abstract}
Photoautotrophic biofilms play an important role in various aquatic habitats and are composed of prokaryotic and/or eukaryotic organisms embedded in extracellular polymeric substances (EPS). We have isolated diatoms as well as bacteria from freshwater biofilms to study organismal interactions between representative isolates. We found that bacteria have a strong impact on the biofilm formation of the pennate diatom Achnanthidium minutissimum. This alga produces extracellular capsules of insoluble EPS, mostly carbohydrates (CHO), only in the presence of bacteria (xenic culture). The EPS themselves also have a strong impact on the aggregation and attachment of the algae. In the absence of bacteria (axenic culture), A. minutissimum did not form capsules and the cells grew completely suspended. Fractionation and quantification of $\mathrm{CHO}$ revealed that the diatom in axenic culture produces large amounts of soluble CHO, whereas in the xenic culture mainly insoluble CHO were detected. For investigation of biofilm formation by A. minutissimum, a bioassay was established using a diatom satellite Bacteroidetes bacterium that had been shown to induce capsule formation of A. minutissimum. Interestingly, capsule and biofilm induction can be achieved by addition of bacterial spent medium, indicating that soluble hydrophobic molecules produced by the bacterium may mediate the diatom/bacteria interaction. With the designed bioassay, a reliable tool is now available to study the chemical interactions between diatoms and bacteria with consequences for biofilm formation.
\end{abstract}

Key index words: Achnanthidium; biofilm; capsule; diatom; EPS

Abbreviations: AHL, N-Acyl-L-homoserine lactones; BM, Bacillariophycean Medium; chl, chlorophyll;
CHO, carbohydrates; d, days; EPS, extracellular polymeric substances; Ft, flow-through; glcBM, BM supplemented with glucose; HA, hot alkali soluble EPS; HB, hot bicarbonate soluble EPS; HW, hot water soluble EPS; LB, Luria-Broth Medium; OD, optical density; SE, soluble EPS; SPE, solid phase extraction; SD, standard deviation; Wf, wash fraction; WW, warm water soluble EPS

Photoautotrophic biofilms are a typical feature in the littoral zones of lakes, streams and oceans. Stones or any other substrata can be covered by a brownish or greenish mucous layer, whenever sufficient light and water is available. These biofilms are a habitat of high primary production (Wetzel 1964) and may be responsible for sediment stabilization (WigglesworthCooksey et al. 2001). However, biofilms also have negative effects, as for instance biofouling on human made surfaces like ship hulls or pipes causes high costs in shipping and water management (Gaylarde and Morton 1999, Schultz et al. 2011, Wingender and Flemming 2011). In addition to the influence of exogenous factors like light, wave disturbance, temperature, water level fluctuations as well as grazing pressure (Hoagland and Peterson 1990, Schmieder et al. 2004, Rao 2010), the formation of photoautotrophic biofilms may be strongly influenced by the physiology of the inhabitants of the biofilms and their interactions (Bruckner et al. 2008). Diatoms are common members and early colonizers of photoautotrophic biofilms (Cooksey and Wigglesworth-Cooksey 1995, Wetherbee et al. 1998) and their productivity may have a strong influence on the whole biofilm. They can produce copious amounts of extracellular polymeric substances (EPS; Myklestad et al. 1989) which are classified as cell bound EPS like stalks, tubes and capsules (Hoagland et al. 1993) or soluble EPS (SE). Diatoms are generally associated with bacteria belonging mostly to Alpha-, Beta- and GammaProteobacteria, to the Cytophaga-Flavobacteria-Bacteroides (CFB) group and to Actinobacteria (Knoll et al. 2001, Sapp et al. 2007, Stanish et al. 2012). Interactions 
between diatoms and bacteria may occur on different levels and may span from synergy via competition to parasitism or defense reactions (Amin et al. 2012). Algae as primary producers provide organic substrates which serve as energy and carbon source for heterotrophic bacteria (Cole 1982). Bell and Mitchell (1972) introduced the "phycosphere" concept, describing the zone around the algal cell "in which bacterial growth is stimulated by extracellular products of the alga." The diatoms may in turn require essential compounds from the bacteria (e.g., vitamins; Croft et al. 2005). Little is known about the molecular processes underlying diatom/bacteria interactions within these biofilm communities. Biofilm inhabitants may affect the physiology of other organisms by soluble molecules, indicating that many of these inter-species interactions are based on chemical signals released by diatoms and by bacteria. Thomas and Robinson (1987) observed that the exudates of the xenic diatom Amphora coffeaeformis lead to enhanced tolerance of the diatom against copper and tributyltinfluoride. This suggests that either bacterial substances themselves or algal exudates induced by bacteria may trigger the stress response of A. coffeaeformis. Such unknown substances may act as signals that mediate recognition and communication between the interaction partners or directly cause a specific effect as toxic compounds. Amin et al. (2012) suggested that substances which are used for intra-species communication, like autoinducers in bacterial quorum sensing or pheromones in the case of diatoms, might also be involved in interactions between diatoms and bacteria. Such interkingdom signaling was already described to play a role for the seaweed Ulva, where zoospores are attracted by bacterial biofilms via released $N$-Acyl-L-homoserine lactones (AHLs; Joint et al. 2007). These AHLs are common autoinducers of Gram-negative bacteria (Chhabra et al. 2005). However, as Amin et al. (2012) stated, a reliable bioassay comprising a diatom-bacterium pair with a stable interdependency is needed to elucidate the molecular and chemical basis of these interactions.

The goal of this study was to establish a model system for studying the interaction of benthic diatoms and bacteria during biofilm formation. A basic requirement for the investigation of a diatom/bacterium pair is the demonstration of a strong phenotype change in the diatom when cultivated in presence or absence of the bacterium. The model organisms utilized here, Achnanthidium minutissimum (Kützing) Czarnecki and Bacteroidetes strain 32, have been isolated by us from photoautotrophic, epilithic biofilms taken from the littoral zone of Lake Constance. A. minutissimum (renamed from Achnanthes minutiss ima, Kützing; Czarnecki 1994) is one of the most abundant freshwater diatoms (Patrick and Reimer 1966, Krammer and Lange-Bertalot 1991). It is frequently found in epilithic biofilms of Lake Constance and represents a eukaryotic pioneer during the initial processes of biofilm formation (Sekar et al. 2004). Common EPS structures of this diatom are stalks and capsules (Geitler 1977) which were described in the literature as "unidirectionally deposited, multilayered structures attaching cells to substrata” for stalks and "material external to the wall and often sloughed into the environment" for capsules (Hoagland et al. 1993). Bacteria of the Bacteroidetes phylum are frequently associated with diatoms (Amin et al. 2012) and were also found to be prominent in xenic diatom isolates from photoautotrophic epilithic biofilms of Lake Constance (Bruckner et al. 2008). Bacteroidetes strain 32 belongs to the Dyadobacter genus. Bacteria of this group were found in freshwater, soil samples, or to be associated with maize (Chelius and Triplett 2000, Baik et al. 2007, Zhang et al. 2010).

MATERIALS AND METHODS

Organisms and cultivation conditions. Achnanthidium minutissimum (Kützing) Czarnecki was isolated from photoautotrophic epilithic biofilms of Lake Constance (Windler et al. 2012). The diatom was either cultivated with co-isolated bacteria as "xenic culture" or additionally as "axenic culture" after removal of associated bacteria as described earlier (Windler et al. 2012). The diatom stock cultures were cultivated in a modified liquid Bacillariophycean Medium (BM; Windler et al. 2012) in cell culture flasks with ventilation caps (Sarstedt, Newton, NC, USA), in which the cells could form a biofilm on the vessel surface. Monthly, these cultures were scraped off and sub-cultured in new BM. For aggregation, the xenic and axenic diatom cultures were cultivated at $100 \mathrm{rpm}$ on an orbital shaker (type 3019; GFL, Burgwedel, Germany). The diatom cultures were exposed to a 12:12 h light:dark cycle with a light intensity of $20-50 \mu \mathrm{mol}$ photons $\cdot \mathrm{m}^{2} \cdot \mathrm{s}^{1}$ at $16^{\circ} \mathrm{C}$ (in this study denoted as standard cultivation conditions for diatoms).

Bacteroidetes strain 32 was isolated by Bruckner et al. (2008). This bacterium was enriched from a xenic Cymbella microcephala Grunow strain D-32 culture, which originated from photoautotrophic, epilithic biofilms from the same sampling site as A. minutissi mum $\left(47^{\circ} 41^{\prime} \mathrm{N} ; 9^{\circ} 11^{\prime} \mathrm{E}\right.$, Germany). The bacterium was cultivated at $22^{\circ} \mathrm{C}$ on agar plates containing $50 \%$ (v/v) Luria-Broth medium (diluted LB; Miller 1972), sub-cultivated monthly, and stored at $4^{\circ} \mathrm{C}-8^{\circ} \mathrm{C}$.

In the following, A. minutissimum together with all co-isolated bacteria is termed a "xenic culture", whereas the purified diatom in co-culture with $B a c$ teroidetes strain 32 is termed a "co-culture".

Bioassay for biofilm formation. Achnanthidium minu tissimum was cultivated either in the presence of bacteria, the sterile supernatant of Bacteroidetes strain 32 , or single fractions of the respective bacterial supernatant. The assays were conducted in well 
plates (\#677180, Cellstar; Greiner Bio-One, Frickenhausen, Germany). Axenic diatom cells were washed with fresh $\mathrm{BM}$ and $10^{5}-2.8 \times 10^{6}$ cells $\cdot \mathrm{mL}^{1}$ were used per well, however, in each single experiment the same cell density was used for test cultures and control cultures. Bacterial cells, supernatant of the bacterial culture or single fractions of the bacterial supernatant, which were prepared as described below, were added and the cultures were complemented with BM to a total volume of $500 \mu \mathrm{L}$. Cultivation was performed at standard cultivation conditions for diatoms for at least $11 \mathrm{~d}$ and was stopped by gently removing the culture supernatant. Staining with crystal violet solution or alcian blue was performed as described below.

Staining procedures and microscopy. Carbohydrates $(\mathrm{CHO})$ associated with cells were stained either with alcian blue or crystal violet. For crystal violet staining, we used a 1:100 dilution of the Gram-staining reagent described by Kaplan and Fine (2002). Supernatants of the diatom cultures were gently removed, the dye was added to the cultures and incubated for $1 \mathrm{~min}$. Excessive dye was removed and the cultures were rinsed with water to remove non-attached cells (Izano et al. 2007). To quantify biofilm formation, crystal violet was extracted from the cultures with $1 \mathrm{~mL}$ ethanol and the absorption of the dye was determined photometrically at $580 \mathrm{~nm}$. The alcian blue dye solution was modified according to Staats et al. (1999), here alcian blue $(1 \%(\mathrm{w} / \mathrm{v})$ in $3 \%$ acetic acid (Roth, Karlsruhe, Germany)) was added and the cultures were washed once with water.

Cells were observed with an upright light microscope (Olympus BX51; Olympus Europe, Hamburg, Germany), equipped with the filter set 41020 (Chroma Technology Corp, Rockingham, VT, USA) or by using an inverted light microscope (Axiovert 40 C; Carl Zeiss MicroImaging $\mathrm{GmbH}$, Göttingen, Germany). Images were taken with the Zeiss AxioCam MRm or MRc digital camera systems (Carl Zeiss MicroImaging GmbH, Oberkochen, Germany).

Cocultivation with bacteria. For the co-cultivation experiments, Bacteroidetes strain 32 was grown in diluted LB $(50 \%(\mathrm{v} / \mathrm{v}))$, washed three times with $\mathrm{BM}$ to remove the bacterial medium and the bacterial suspension was adjusted to an optical density at $600 \mathrm{~nm}\left(\mathrm{OD}_{600}\right)$ of 0.1 , of which $5 \mu \mathrm{L}$ were applied to the bioassay. The xenic A. minutissimum cultures were inoculated with the same chlorophyll (chl) concentration as the axenic cultures and the co-cultures (for chl measurement see below).

Incubation with bacterial spent medium. For those experiments requiring the sterile supernatant of the bacterial culture, Bacteroidetes strain 32 was cultivated in liquid BM supplemented with $10 \mathrm{mM}$ glucose (glcBM) at $20^{\circ} \mathrm{C}$ and $135 \mathrm{rpm}$. The supernatant of the bacterial culture was harvested when the culture reached an $\mathrm{OD}_{600}$ of 0.2 . The culture was centrifuged at $5,525 \mathrm{~g}$ (Allegra ${ }^{\mathrm{TM}}$ 25R centrifuge with TS-
5.1-500 rotor and swinging buckets, 10 or $50 \mathrm{~mL}$ tubes, depending on the volume of the supernatant, Beckman Coulter, Krefeld, Germany) and the supernatant was filtefred using a $0.2 \mu \mathrm{m}$ filter (Filtropur $\mathrm{S}$; Sarstedt, Nümbrecht, Germany). For filtration of large volumes of bacterial supernatant $(>10 \mathrm{~mL})$, the bacterial supernatant was additionally prefiltered through $3.0 \mu \mathrm{m}$ membrane filter (Merck Millipore, Darmstadt, Germany) and $0.2 \mu \mathrm{m}$ filter (Whatman, Dassel, Germany). The sterility of the filtrate was randomly tested by plating an aliquot on agar plates containing diluted LB medium $(50 \%$ (v/v)) and incubated as described for Bacteroidetes strain 32. Different volumes of the sterile bacterial supernatant and equivalent volumes of glcBM for negative control were applied to the bioassay.

For fractionation, $10 \mathrm{~mL}$ of the bacterial supernatant were separated via solid-phase extraction (SPE) using C18-SPE endcapped cartridges (530 mg; Marcherey-Nagel, Düren, Germany) according to Von Elert and Pohnert (2000). The bacterial supernatant and medium control were adjusted to $\mathrm{pH} 7$ with citric acid or sodium hydroxide. Flow-through (Ft), wash fraction (Wf) and eluate were collected separately. Ft and Wf were evaporated to near dryness and diluted in $1 \mathrm{~mL}$ BM. The eluate was evaporated to dryness to remove methanol and resuspended in $2 \mathrm{~mL}$ BM. Aliquots of this fraction were incubated for $1 \mathrm{~h}$ at $30^{\circ} \mathrm{C}$ and $80^{\circ} \mathrm{C}$, respectively, for further dissolution of solid material. The bacterial growth medium (glcBM) was treated the same way and was used as a negative control. The fractions were sterile filtered as described above and aliquots were diluted to the original concentration (1:5 for the eluate, 1:10 for Ft and Wf). $250 \mu \mathrm{L}$ of the concentrated and diluted fractions were applied to the bioassay and tested for bioactivity. The unseparated bacterial supernatant was used as positive control.

For further fractionation, $910 \mathrm{~mL}$ of the sterile bacterial supernatant were loaded on an endcapped C18-SPE column (10 g; Marcherey-Nagel) and were eluated stepwise with methanol at increasing concentrations $(20 \%, 40 \%, 60 \%, 80 \%$, and $100 \%$ methanol in ultrapure water). Each fraction was eluted with $20 \mathrm{~mL}$ of the solvent, except the $100 \%$ methanol fraction. This fraction was eluted with $25 \mathrm{~mL}$. After evaporation, the residues were resuspended in $1 \mathrm{~mL}$ of ultrapure water, sterile filtered, and diluted in BM. $250 \mu \mathrm{L}$ of the diluted fractions were tested for bioactivity.

The sterile bacterial supernatant was harvested at different growth phases of Bacteroidetes strain 32, which was cultivated in $100 \mathrm{~mL}$ glcBM in triplicates. $1.2 \mathrm{~mL}$ were removed at each time point. A total of $100 \mu \mathrm{L}$ were used to measure $\mathrm{OD}_{600}$ of the bacterium and the supernatant of the remaining volume was sterile filtered as described above. Half of the volume was frozen for determination of the glucose concentration via HPLC as described in Jagmann 
et al. (2010). The other half volume was stored at $4^{\circ} \mathrm{C}$ until it was tested for bioactivity $(50 \%(\mathrm{v} / \mathrm{v})$ of the bacterial supernatants).

Growth of A. minutissimum in xenic and axenic cul tures. Growth of axenic and xenic A. minutissimum and of the diatom co-cultured with Bacteroidetes strain 32 was measured. The bioassay was performed as described above and the chl concentrations of suspended cells in the supernatants (non-adherent cells) and of cells embedded in the biofilm (adherent cells) were determined as described below.

Quantification of soluble and bound EPS. Triplicates of xenic as well as axenic cultures were incubated in $100 \mathrm{~mL} \mathrm{BM}$ in cell culture flasks at standard diatom cultivation conditions. The axenic cultures were inoculated at a cell density of $10^{3}$ cells $\cdot \mathrm{mL}^{1}$. The chl concentrations were determined as described below and the xenic cultures were inoculated at the same chl concentrations as the axenic cultures. Soluble and bound EPS of xenic and axenic A. minu tissimum were stepwise extracted according to the protocol established for isolation of "SE"-, "warm water soluble EPS (WW)"-, "hot water soluble EPS (HW)"-, "hot bicarbonate soluble EPS (HB)"-, and "hot alkali soluble EPS (HA)"-fractions according to Bahulikar and Kroth (2008) with modifications: The cells were scraped from the bottom of the tissue culture flasks and the suspensions were centrifuged for $20 \mathrm{~min}$ at $5,525 \mathrm{~g}$ and $20^{\circ} \mathrm{C}$ (Allegra ${ }^{\mathrm{TM}} 25 \mathrm{R}$ centrifuge with TS-5.1-500 rotor and $50 \mathrm{~mL}$ swinging buckets, Beckman Coulter). The supernatants containing the soluble $\mathrm{CHO}$ were carefully separated by decanting from the cell pellets containing the bound CHO. The supernatants were concentrated to $5 \mathrm{~mL}$ using a rotatory evaporator. Polymers were precipitated overnight in five volumes of $96 \%$ ethanol at $-20^{\circ} \mathrm{C}$. The precipitates were centrifuged for $20 \mathrm{~min}$ and $4^{\circ} \mathrm{C}$ at $4,300 \mathrm{~g}$ without active deceleration (Megafuge 1.0R with swing-out rotor \#2705; Heraeus Instruments, Hanau, Germany), the pellets were dried under nitrogen gas and subsequently dissolved in $1 \mathrm{~mL}$ ultrapure water. To increase solubility, the suspensions were acidified with $2-10 \mu \mathrm{L}$ concentrated $\mathrm{H}_{2} \mathrm{SO}_{4}$ and heated to $60^{\circ} \mathrm{C}-80^{\circ} \mathrm{C}$ when required to dissolve the pellets. The ethanol fractions containing the oligo-and monomers were evaporated and the pellets were dried and processed as described for the polymers.

The bound CHO were extracted stepwise. First, the cell pellets were resuspended in $1 \mathrm{~mL}$ sterile-filtered tap water to keep the osmolarity in the physiological range and incubated for $1 \mathrm{~h}$ at $30^{\circ} \mathrm{C}$ and $300 \mathrm{rpm}$. Cells were centrifuged $(5,000 \mathrm{~g}$ for $10 \mathrm{~min}$ at $20^{\circ} \mathrm{C}, 5417 \mathrm{R}$ microcentrifuge; Eppendorf, Hamburg, Germany) and the supernatants containing the "WW" fraction were separated from the pellets. The following centrifugation steps were conducted at $5,000 \mathrm{~g}$ for $7 \mathrm{~min}$ at $4^{\circ} \mathrm{C}(5417 \mathrm{R}$ microcentrifuge; Eppendorf). Pellets were defatted by incubation in $1 \mathrm{~mL} 90 \%$ ethanol at $600 \mathrm{rpm}$ for $15 \mathrm{~min}$ and sub- sequently centrifuged (Wustman et al. 1997, Bahulikar and Kroth 2008). This procedure was repeated 5-7 times until the pellets were colorless or slightly green. Cells were further washed twice with distilled water, then incubated in $1 \mathrm{~mL}$ distilled water at $90^{\circ} \mathrm{C}$ for $1 \mathrm{~h}$ and centrifuged. The supernatants were used for determination of the "HW" and the cell pellets were incubated for $1 \mathrm{~h}$ in $1 \mathrm{~mL} 0.5 \mathrm{M}$ $\mathrm{NaHCO}_{3}$ and $0.1 \mathrm{M}$ EDTA at $95^{\circ} \mathrm{C}$ (Chiovitti et al. 2003) to harvest the "HB". The remaining portion of the bound EPS was extracted by resuspending the pellets in $1 \mathrm{~mL} 1 \mathrm{M} \mathrm{NaOH}$ and $0.2 \mathrm{M} \mathrm{NaBH}_{4}$ at $95^{\circ} \mathrm{C}$ for $1 \mathrm{~h}$ and subsequent centrifugation of the cell fragments, resulting in "HA". Mono-/oligo- and polysaccharides of the soluble $\mathrm{CHO}$ fraction as well as the total CHO content of the WW-, HW-, HB-, and HA- fractions were measured using the phenolsulfuric acid assay (Dubois et al. 1956) with glucose as standard according to De Brouwer et al. (2002) and Bruckner et al. (2008) and were specified as $\mu \mathrm{g}$ $\mathrm{CHO}$ per $\mu \mathrm{g}$ chl $\left(\mu \mathrm{g} \mathrm{CHO} \cdot(\mu \mathrm{g} \text { chl })^{1}\right)$. In a followup experiment, we compared a standard curve for glucose with those of other $\mathrm{CHO}$ that were reported to be prevalent in A. minutissimum (Bahulikar and Kroth 2008). Glucose had the steepest regression slope (see Appendix S1 and Fig. S1 in the Supporting Information), indicating that other $\mathrm{CHO}$ might have been slightly over-estimated. Glucuronic acid was tested as well and was found to have the lowest regression slope (see Appendix S1 and Fig. S2 in the Supporting Information). It is therefore not included in this study.

Determination of chl concentrations. Chl was extracted by addition of a mixture of $5 \%$ methanol and $95 \%$ acetone to the diatom cell pellet. The chl of surface-adherent cells was extracted by flushing the biofilm with the extraction mixture for several times directly in the cultivation well. Chl concentrations were determined using the equation and extinction coefficients for diatoms, chrysomonads, and brown algae according to Jeffrey and Humphrey (1975), and specified as total chl concentration (a sum of chl $a$ and $c$ ).

\section{RESULTS}

Differences in biofilm formation of xenic and axenic A. minutissimum. Achnanthidium minutissimum is a benthic diatom growing attached to surfaces. Interestingly, we observed that xenic and axenic A. minu tissimum cells showed very different aggregation behavior. When cultivated on a shaker, the xenic A. minutissimum cells formed macroscopically visible aggregates (Fig. 1A), while the axenic diatom culture grew completely suspended and no aggregate formation was visible (Fig. 1B). Under non-shaking conditions, the xenic diatom cells were attached to the surface of the cultivation vessel, forming a biofilm. Microscopic analyses in combination with alcian blue staining revealed that the cells in the 
early and late stationary phase were surrounded by large capsules of bound EPS (Fig. 1, C and E). The respective diatom cells were attached to each other via the capsules, partially resulting in macroscopically visible aggregates. Cells of the axenic culture did not show any capsules, remaining freely dispersed and forming, if at all, only small aggregates of a few cells (Fig. 1, D and F). In addition to the capsules, the xenic cultures showed diffuse EPS structures that were stainable by alcian blue (Fig. 1C). This diffuse, unstructured form of EPS could also be found in the axenic culture (Fig. 1D).

Bioassay for biofilm formation: Induction of capsule and biofilm formation in the axenic A. minutissimum culture by co cultivation with Bacteroidetes strain 32. A bioassay was designed to investigate the bacterial influence on capsulation/biofilm formation of A. minutissimum. Biofilm formation was quantified according to Izano et al. (2007), by staining of bound CHO with crystal violet. The dye stains the cells as well as the bound EPS and its intensity depends on the amount of attached cells and insoluble EPS and therefore is proportional to the biomass. After staining, biofilm formation is visible by eye and biofilm quantity can be determined by measurement of the alcohol-extracted crystal violet.

We found that the biofilm formation of the xenic culture and of the co-culture with Bacteroidetes strain 32 is accompanied by much higher crystal violet staining compared with the axenic diatom culture (Fig. 2A). The stable biofilm of the xenic cultures allowed rough washing steps because the cells adhered strongly to the plastic surface of the wells, resulting in high crystal violet absorption already after $3 \mathrm{~d}$ of cultivation (Fig. 2B). At that time, the chl concentrations were still relatively low in the xenic culture $\left(0.38 \mu \mathrm{g} \cdot \mathrm{mL}{ }^{1}\right.$; see below Fig. $\left.5 \mathrm{~A}\right)$. The co-culture also exhibited strong biofilm formation after $3 \mathrm{~d}$ and it reached the highest values of crystal violet adsorption after $10 \mathrm{~d}$ (Fig. 2B). After $3 \mathrm{~d}$ of cultivation the diatom cells in the xenic culture and in the co-culture exhibited stalks that apparently mediate adherence in early stages of biofilm formation (Fig. 2C). The cells in the xenic culture started capsule formation after $10 \mathrm{~d}$, those of the co-culture after $14 \mathrm{~d}$ of cultivation, when cells were in the stationary phase. In the axenic culture, there was no biofilm and capsule formation observable even after $24 \mathrm{~d}$. Here, the cells did not adhere to the well surface and were removed during the wash steps of the staining procedure. In some cases, crystal violet did not stain the capsules properly when the biofilm was fully developed. In these cases, the cultures were additionally stained with alcian blue for microscopic observation and visualization of capsules in the xenic culture and co-culture (Fig. 2C).

Capsule and biofilm induction by the sterile superna tant of Bacteroidetes strain 32. Bacteroidetes strain 32 was cultivated in BM supplemented with $10 \mathrm{mM}$ glucose (glcBM) before harvesting the spent medium. This medium allowed bacterial growth without inhibiting diatom growth as we observed for diluted LB. Capsule and biofilm formation of A. minutissi mum can be induced by incubation of the axenic culture with the filtered sterile supernatant of Bacter oidetes strain 32 (Fig. 3). The intensities of crystal violet adsorption of A. minutissimum cultures showed a dose-dependent pattern when treated with different volumes of the sterile bacterial supernatant and reached a maximal absorption after addition of $25 \%$ and $50 \%(\mathrm{v} / \mathrm{v})$ of the bacterial supernatant (Fig. 3A). Diatom capsules were found in cultures which had been supplemented with $12.5 \%, 25 \%$, and $50 \%(\mathrm{v} / \mathrm{v})$ of the bacterial supernatant. Neither the control cultures, which had been treated with the glcBM only, nor the axenic culture did induce biofilm or capsule formation. This indicates that soluble molecules released by the bacterium induce biofilm and capsules of $A$. minutissimum.

For enrichment of the biofilm-inducing substance, we further separated the bacterial supernatant by solid phase extraction (SPE) according to Von Elert and Pohnert (2000). The fractions were diluted to the original concentration prior to the application (Fig. 3B). The eluted fraction (Elu) showed a similar induction of capsule/biofilm formation as the unseparated
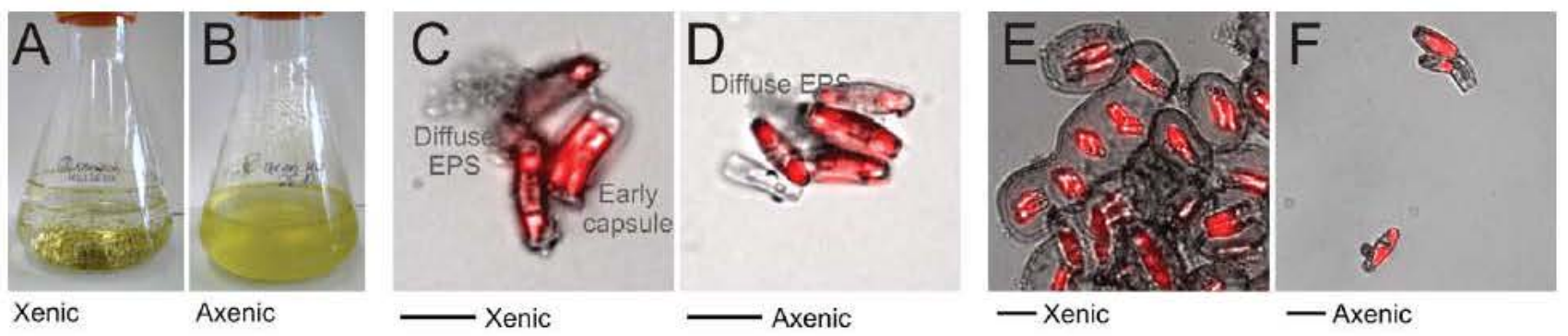

Fic. 1. Xenic (A, C, E) and axenic (B, D, F) cultures of the diatom Achnanthidium minutissimum. The xenic cultures formed macro scopic visible aggregates when cultivated on a shaker (A), while the axenic cells grew suspended (B). Alcian blue stained cells with diffuse EPS in the xenic (C) and axenic (D) cultures and early capsule formation in the xenic culture in the early stationary phase. In the late sta tionary phase, capsules of the xenic culture are fully developed (E), but missing in the axenic culture (F). Autofluorescence of the chl appears as bright red area in the cells. Scale bars denote $10 \mu \mathrm{m}$. 

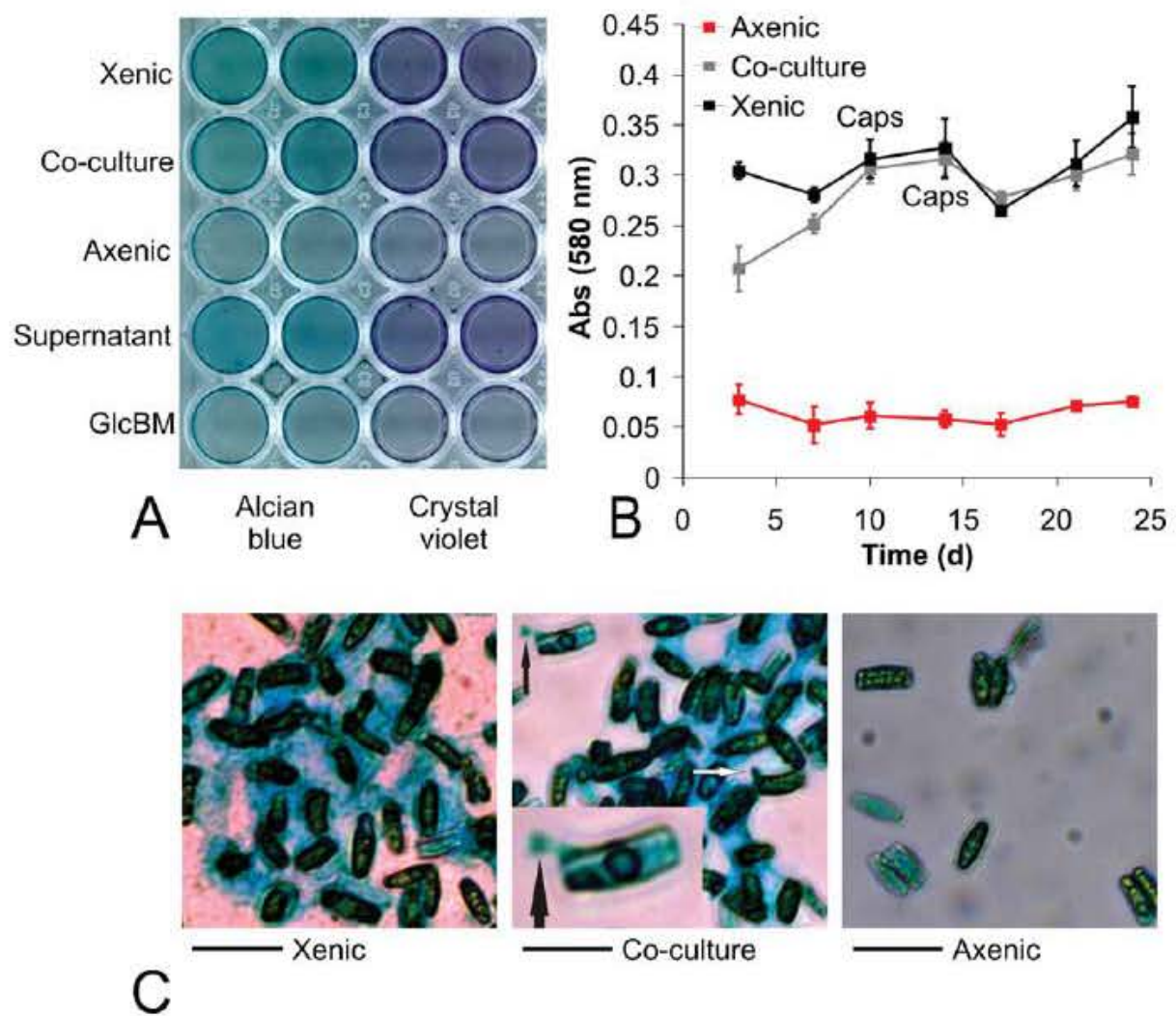

FiG. 2. Bioassay for biofilm formation. Induction of capsule and biofilm formation in the axenic Achnanthidium minutissimum culture. (A) Alcian blue or crystal violet stained cultures of the diatom cultivated in a 48 well plate. Biofilms of the diatom in co culture or treated with the sterile bacterial supernatant show a stronger staining, comparable to the xenic culture. The control cultures (Axenic and GlcBM) show only faint staining $(n$ 2). (B) Absorption of crystal violet extracted from the axenic culture, the co culture with Bacteroidetes strain 32 and the xenic diatom culture. (Caps) marks time points when capsules appeared $(n$ 3; error bars indicate standard deviation (SD)). (C) Microscopic images: Cells of the xenic culture, co culture with Bacteroidetes strain 32 and axenic A. minutissimum culture stained with al cian blue after $21 \mathrm{~d}$ of cultivation. Arrows mark stalks of the diatom cells. Cell with stalk is pictured in the middle picture with $2 \times$ magnifi cation. Scale bars denote $20 \mu \mathrm{m}$.

bacterial spent medium (positive control). Ft and Wf of the extracted bacterial spent medium described above did not induce a stronger biofilm formation than the fractions of the bacterial growth medium, indicating that the biological activity had been completely absorbed by the nonpolar C18sorbent and was released after extraction with methanol. Incubation of the bioactive fraction at $30^{\circ} \mathrm{C}$ and $80^{\circ} \mathrm{C}$ as well as evaporation to dryness did not diminish the biological activity. As the methanol that was used as solvent for the fractionation had been completely evaporated, we can exclude induction of capsule and biofilm formation by the alcohol itself. Furthermore, the SPE was performed with bacterial growth medium only. Here, no capsule or biofilm formation was observed in any of the fractions.

Furthermore, the bioactivity was found in fractions which were eluted with high methanol concentrations, thus increased biofilm formation was mainly found in A. minutissimum cultures which had been treated with the $60 \%-100 \%$ methanol fractions and capsules were only found in the $80 \%-100 \%$ methanol fractions (Fig. 3C). These results suggest a nonpolar character of the bioactive molecule, as well as resistance to heat and dryness. The observed effect of bacterial supernatant on A. minutissimum is very reproducible, we were able to repeat the experiments several times independently starting from different bacterial cultures and purifying the bioactive compound(s) to varying degrees (data not shown).

To investigate the optimal growth phase of the bacterium for sufficient production of the bioactive substance, the bacterial supernatant was harvested at different time points and each supernatant was tested for bioactivity. Figure 4A shows the growth of Bacteroidetes strain 32 in glcBM reaching an $\mathrm{OD}_{600}$ of 0.24 in the stationary phase. Glucose consumption, as determined via HPLC analysis, resulted in a decrease of the glucose concentration from 10.3 to $8.5 \mathrm{mM}$ during this time. Biofilm formation of A. minutissimum, as based on an increase in extractable crystal violet adsorption from 0.16 to 0.35 , was already induced by bacterial supernatant taken in the early exponential phase of the bacterium at an $\mathrm{OD}_{600}$ of 0.016 (Fig. 4B). Accordingly, capsule formation was only induced by supernatants taken 

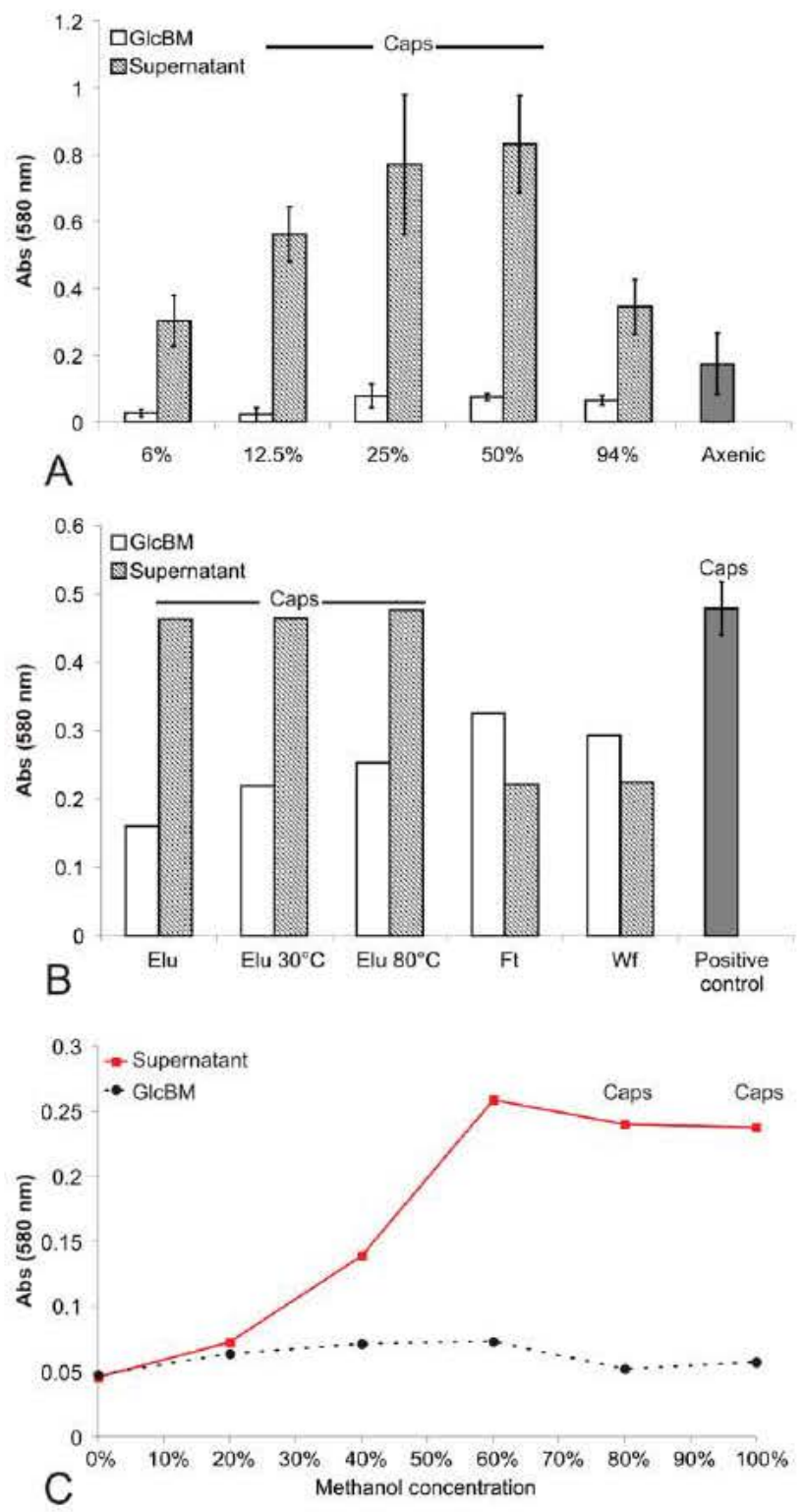

Fic. 3. Induction of capsule and biofilm formation of Achnan thidium minutissimum by sterile bacterial supernatant of Bacteroidetes strain 32. Biofilms were stained with crystal violet and the absorp tion of the dye was determined. Cultures exhibiting capsules are marked with (Caps). (A) Incubation with 6\%, 12.5\%, 25\%, 50\%, and $94 \%(\mathrm{v} / \mathrm{v})$ of the sterile supernatant $\left(\begin{array}{ll}n & 3\end{array}\right)$. The control assays were conducted either with addition of equivalent volumes of the bacterial medium (glcBM) or the axenic diatom culture. (B) A. minutissimum incubated with different fractions of the C18 solid phase separated bacterial supernatant: eluate (Elu), eluate preheated to $30^{\circ} \mathrm{C}$ and $80^{\circ} \mathrm{C}$, respectively (Elu $30 / 80^{\circ} \mathrm{C}$ ), flow through (Ft) and wash fraction (Wf). Graphs show cultures trea ted with fractions which had been diluted to the original concen tration. Fractions of the bacterial medium glcBM and the unseparated bacterial supernatant were used for negative and positive control ( $n \quad 1$ for the fractions, $n \quad 3$ for the control). (C) A. minutissimum incubated with different fractions of the C18 SPE separated bacterial supernatant, eluted with increasing meth anol concentrations ( $n$ 2). Fractions of the bacterial growth medium glcBM were used for negative controls (lower curve). Error bars indicate SD. after the bacterium reached the mid-exponential phase at an $\mathrm{OD}_{600}$ of 0.03 .

Growth of A. minutissimum in xenic and axenic cultures. Growth of A. minutissimum in the bioassays was determined by measuring the chl concentrations (Fig. 5). This method was chosen, because both co-culture and xenic culture tended to form cell aggregates, which hampered reproducible cell counting. The axenic culture reached a similar maximum chl content as the xenic culture and the coculture $\left(0.78 \pm 0.13 \mu \mathrm{g} \cdot \mathrm{mL}^{1}\right.$ after $10 \mathrm{~d}$ for the axenic culture, $0.86 \pm 0.05 \mu \mathrm{g} \cdot \mathrm{mL}^{1}$ and $0.81 \pm 0.06 \mu \mathrm{g} \cdot \mathrm{mL}^{1}$ after $7 \mathrm{~d}$ for the xenic culture and co-culture, respectively; Fig. 5A). Interestingly, the chl content of the xenic culture and of the co-culture showed a plateau in the stationary phase after $17 \mathrm{~d}$ of cultivation, whereas the chl concentration of the axenic culture decreased continuously. In the xenic culture and in the co-culture, the main chl concentrations were found in the biofilm fraction, indicating that these cultures consist mostly of adherent cells (Fig. 5, B and C). Nearly no chl was detected in the supernatant after 10 and $14 \mathrm{~d}$ of cultivation, respectively, at a time when the cells exhibit capsules. In contrast, most of the chl of the axenic culture was found in the nonadherent fraction (Fig. 5D). The bacterium itself was not able to grow without the diatom in the diatom full medium (BM; Appendix S1 and Fig. S3 in the Supporting Information).

Analysis of carbohydrates. We analyzed the CHO content and quality by stepwise extraction of soluble and insoluble EPS from xenic and axenic A. minu tissimum contents as described in Materials and Methods. Quantification of CHO in each fraction showed that in the late exponential growth phase (after $12 \mathrm{~d}$ of cultivation), the axenic and xenic cultures exhibited similar amounts of bound $\mathrm{CHO}$ (Fig. 6A). At that time, the xenic diatoms did not show capsules and the axenic cells secreted about 5-fold more soluble $\mathrm{CHO}$ compared with the xenic culture. In the early stationary phase, after $20 \mathrm{~d}$ of cultivation, the amount of bound $\mathrm{CHO}$ in the $\mathrm{HB}$ fraction of the xenic culture increased (Fig. 6B) and light microscopy indicated that the xenic cells started to form capsules (Fig. 1C). The capsules were fully developed in the late stationary phase, after $33 \mathrm{~d}$, when the $\mathrm{HW}$ and $\mathrm{HB}$ fractions exhibited large amounts of insoluble CHO (Figs. $1 \mathrm{E}$ and 6C). Microscopic observations revealed that dissolution of capsular material correlated well with an increase in $\mathrm{CHO}$ content in the $\mathrm{HW}$ and $\mathrm{HB}$ fractions (Appendix S1 and Fig. S4 in the Supporting Information). Thus, the capsular material of the xenic culture can be extracted with the hot water and hot bicarbonate treatments, leaving only very little CHO material in the hot alkali fraction. During the whole cultivation period, the amount of soluble 

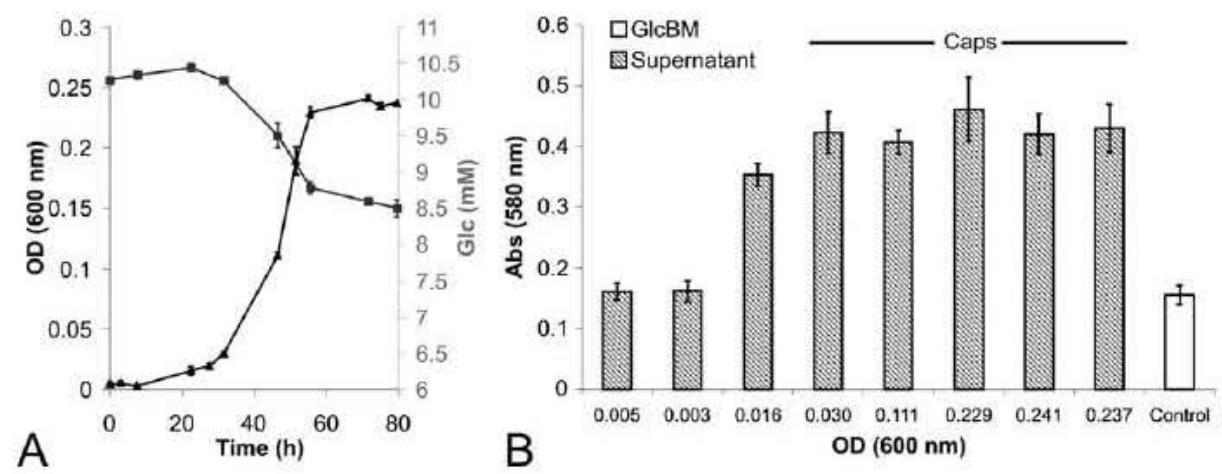

FIG. 4. Biofilm induction according to different growth phases of Bacteroidetes strain 32. (A) Optical density (OD) of the bacterium in glcBM (black line) and simultaneous decrease of the glucose concentration (gray line). (B) Intensity of the crystal violet extracted from Achnanthidium minutissimum cultures treated with sterile supernatants of Bacteroidetes strain 32, harvested at different growth phases of the bacterium (given in OD). (Caps) indicates capsule formation. The diatom culture was treated with glcBM for control ( $n$ 3; error bars indicate SD).

CHO remained relatively low in the xenic culture, especially in the monomer fractions (Fig. 6). The axenic A. minutissimum, on the other hand, showed less $\mathrm{CHO}$ in the insoluble fractions but produced large amounts of soluble CHO.

\section{DISCUSSION}

When cultivated in presence or absence of distinct bacteria, the diatom A. minutissimum showed a considerably different behavior regarding cell aggregation, cell attachment and biofilm formation, which is most likely because of changes in the generation of soluble and insoluble EPS by the diatom. Positive as well as negative bacterial influences on aggregation formation have been described in the context of marine snow, aggregated material of cells, and organic matter in the oceans (Grossart et al. 2006, Gärdes et al. 2010), and several possible mechanisms have been discussed. Bacteria may
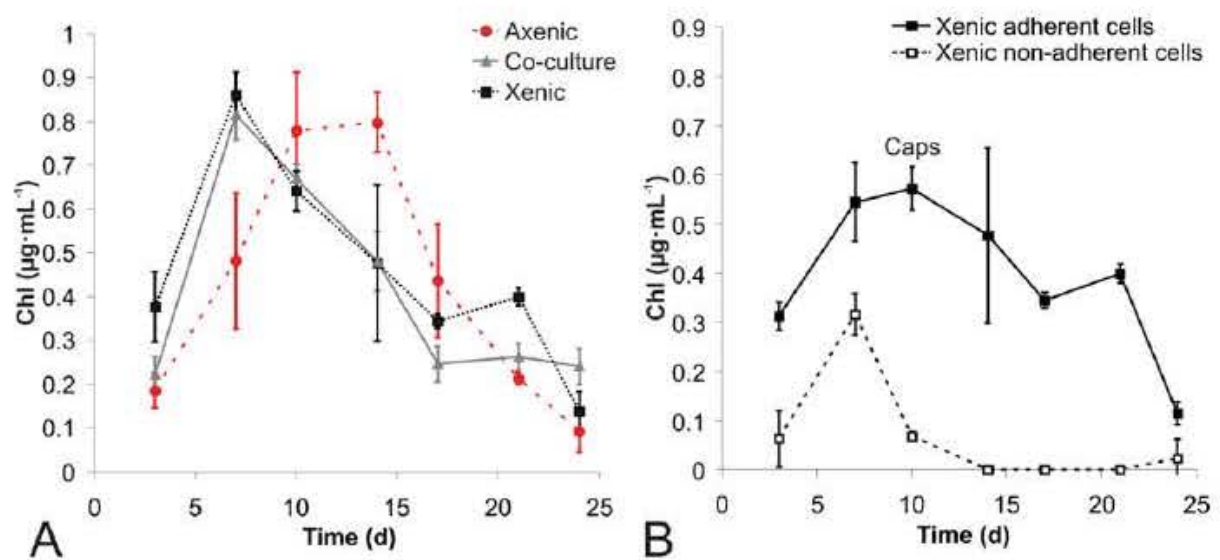

Fig. 5. Chl concentrations of Achnanthidium minutissimum in axenic and xenic conditions and in the co culture with Bacteroidetes strain 32. (A) Sum of the chl concentrations of adherent and non adherent cells of the cultures. (B) Chl concentrations of adherent and non adherent cells of the xenic culture, (C) of the coculture with Bacteroidetes strain 32, and (D) of the axenic culture. Capsules (Caps) in the xenic and co culture are formed after 10 and $14 \mathrm{~d}$ of cultivation, respectively ( $n$ 3; error bars indicate standard deviation). 

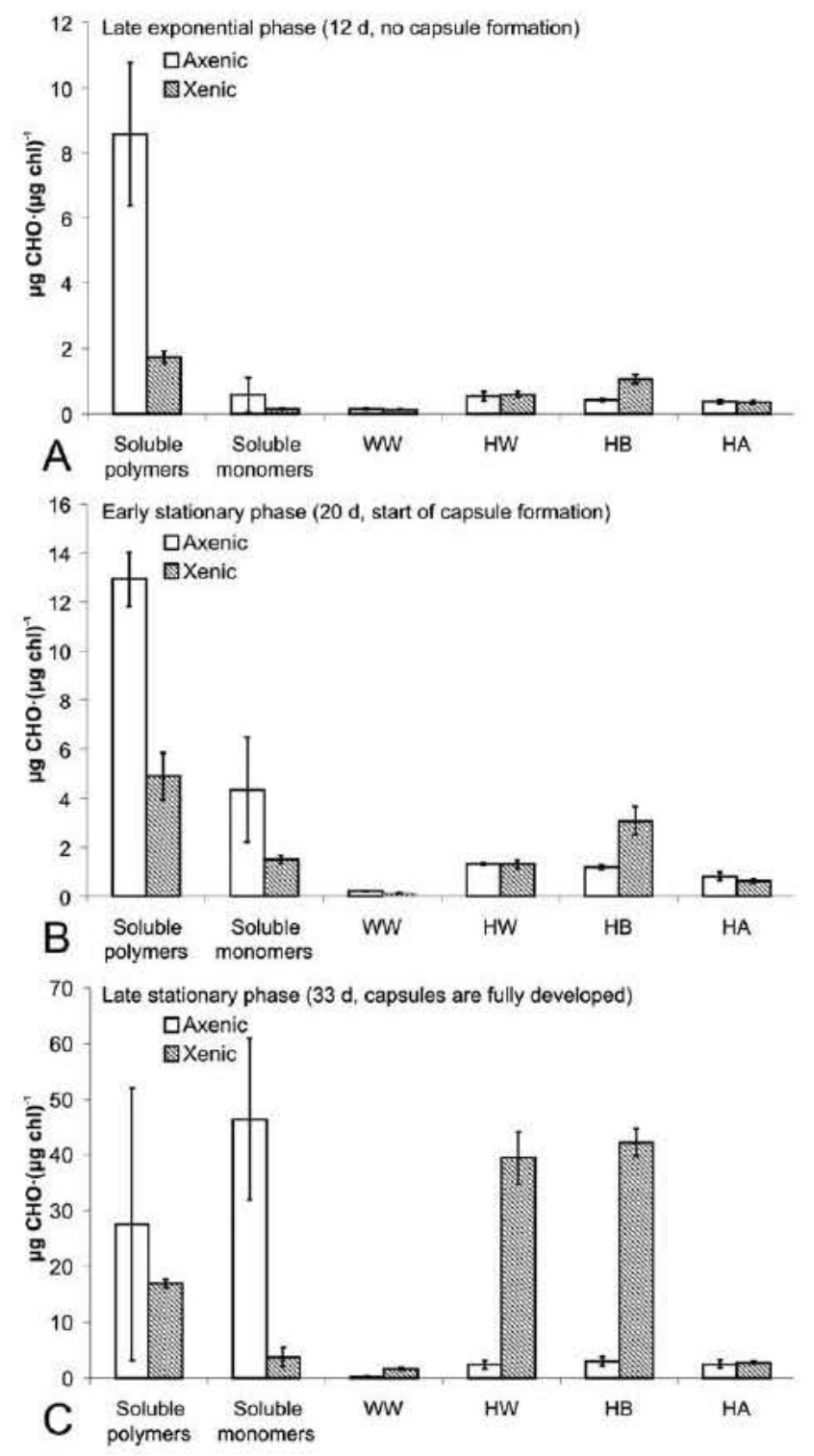

Fig. 6. Quantification of soluble and bound carbohydrates of axenic and xenic Achnanthidium minutissimum cultures. Specific carbohydrate quantities are shown for axenic and xenic cultures and specified in $\mu \mathrm{g}$ carbohydrate per $\mu \mathrm{g}$ chl ( $\left.\mu \mathrm{g} \mathrm{CHO}(\mu \mathrm{g} \mathrm{chl})^{1}\right)$. Carbohydrates were extracted in different growth phases of the diatom: late exponential growth phase (12 d of cultivation), early stationary phase ( $20 \mathrm{~d}$ of cultivation), and late stationary phase (33 d of cultivation). Soluble carbohydrates were measured as sol uble polymers and monomers. Bound carbohydrates were stepwise extracted with warm water (WW), hot water (HW), hot bicarbon ate (HB), and hot alkali (HA). ( $n$ 3; error bars indicate SD).

increase the amount of matrix material either by contribution of bacterial EPS (Decho 1990) or by stimulation of EPS secretion by the algae. Also bacterial modification of organic material and subsequent changes of adhesive properties has been suggested (Grossart et al. 2006). Cellular aggregation is of ecological relevance as it increases the sinking velocity and thus plays an important role in the flux of organic matter into deeper parts of the water column (Fowler and Knauer 1986, Gärdes et al. 2010). It also may alter the consumption by grazers and thereby the transfer of organic matter to upper trophic levels (Decho 1990).

Xenic A. minutissimum cells may stick to the well surface because of development of capsules of extracellular organic matter, while axenic cultures revealed no such capsules and grew suspended. Capsule and biofilm formation of axenic A. minutissi mum, however, can be induced by addition of Bacteroidetes strain 32. Of eight other tested bacterial isolates, several led to stronger biofilm formation, but none of them was able to induce capsule formation (Appendix S1 and Fig. S5 in the Supporting Information). We made similar observations in earlier experiments showing that capsulation and altered EPS structures of the freshwater biofilm diatom Cymbella microcephala occur in co-culture with Bacteroidetes strain 32, indicating that this might be a specific property of the bacterium (Bruckner et al. 2008).

Achnanthidium minutissimum also shows capsule formation when treated with the sterile supernatant of Bacteroidetes strain 32. Apparently, the diatom is able to recognize one or more soluble molecules produced by the bacterium; a direct cell-to-cell contact between the interaction partners apparently is not required as it was shown previously for Pseudo nitzschia multiseries (Kobayashi et al. 2009). Interestingly, Bacteroidetes strain 32 produced the putative infochemicals even when cultivated separately, which indicates a constitutive production and secretion. As the biotic activity of this or these substances can be demonstrated already in the early exponential growth phase of Bacteroidetes strain 32, they apparently are produced by intact bacterial cells and do not constitute substances that are released after cell damage. As shown in Figure 4B, A. minutissimum reacts with a sharp increase in biofilm formation even at relatively low bacterial abundance, thus either the diatom is very sensitive to the substance(s) or the production to the substance(s) is strongly increased once the bacterial density exceeds a certain threshold. The bioactive molecules were extractable via reversed phase cartridges indicating a hydrophobic character, similarly to AHLs, a major class of autoinducers produced by Gram-negative bacteria (Chhabra et al. 2005). The inducibility of capsule formation using spent medium of the bacterium shows that the diatom itself is the active producer of biofilm material and the active contribution of bacterial EPS can therefore be excluded.

Former studies showed that surface materials may influence diatom attachment and biofilm formation (Gawne et al. 1998, Mieszkin et al. 2012). Polystyrene for example, represents a hydrophobic surface and was found to be preferred out of four different materials for attachment of the diatom Achnanthes longipes (Gawne et al. 1998). In our study, axenic A. minutissimum did not attach to polystyrene of the 
well plates and hence attachment only depends on Bacteroidetes strain 32 or its spent medium. Gawne et al. (1998) and Mieszkin et al. (2012) further showed that bacterial biofilms on surfaces may influence attachment of diatoms in a positive or negative way and often precedes biofilm formation of diatoms. As biofilm of A. minutissimum can be also induced by the sterile supernatant of the bacterium, preceding biofilm formation of the bacterium as a sort of base layer is obviously not the only reason for attachment of the alga.

CHO quantification revealed that the axenic diatom culture contained large amounts of soluble CHO. In the late stationary phase, we found variable amounts of soluble polymers in this culture (15.9, 11.1, and $55.6 \mu \mathrm{g} \mathrm{CHO} \cdot(\mu \mathrm{g} \mathrm{chl})^{1}$; Fig. 6C), resulting in a high standard deviation. From former experiments, we know that the axenic cultures usually secrete large amounts of soluble polymeric CHO in the stationary phase (up to $105 \mu \mathrm{g} \mathrm{CHO} \cdot(\mu \mathrm{g}$ chl) ${ }^{1}$; Appendix S1; Fig. S4). However, in the xenic culture insoluble $\mathrm{CHO}$ were dominant, especially in the late-stationary phase when the capsules were fully developed. In this growth phase, CHO of the xenic culture were primarily found in the HW and HB fractions, which correlates well with the dissolution of the capsular material (Fig. S4, C and D), implying that the $\mathrm{CHO}$ content of these fractions derives from capsular material. Absolute values of the $\mathrm{CHO}$ extraction have to be interpreted with caution, as the extraction of bound CHO with warm water is controversially discussed in the literature because of possible contamination with released intracellular CHO (Chiovitti et al. 2004, De Brouwer and Stal 2004). However, we found only little amounts of $\mathrm{CHO}$ in this fraction $(<2 \mu \mathrm{g} \mathrm{CHO} \cdot(\mu \mathrm{g}$ chl) ${ }^{1}$ ) compared to the other fractions. We tried to minimize possible contamination with intracellular $\mathrm{CHO}$ previous to the extraction with warm water as we defatted the cells with ethanol, which was shown to remove intracellular material (Wustman et al. 1997). We checked the reliability of the defatting step and found no CHO left after two extractions with ethanol, suggesting that all intracellular $\mathrm{CHO}$ were removed. Here, axenic and xenic cells released similar amounts of CHO during the defatting steps (see Appendix S1 and Fig. S6 in the Supporting Information).

Glucose has been used as standard for $\mathrm{CHO}$ measurement as described earlier (De Brouwer et al. 2002, Bruckner et al. 2008). To evaluate the difference with the naturally occurring CHO mix of A. minutissimum, we tested six most abundant compounds which were found in A. minutissimum previously (Bahulikar and Kroth 2008) using the Dubois method (Figs. S1 and S2). These sugars yielded a somewhat weaker colorimetric reaction compared with glucose. Thus, the absolute values of the CHO fractions may be overestimated, however, our findings are based on a comparison of $\mathrm{CHO}$ contents in xenic and axenic cultures and not on absolute values.

As bacteria in the xenic culture potentially may consume the soluble CHO (especially the easily accessible monomers, whereas the bound $\mathrm{CHO}$ may be more resistant to bacterial degradation), we cannot estimate whether the total amounts of $\mathrm{CHO}$ in xenic and axenic cultures are comparable. However, it might be possible that axenic and xenic cultures produce similar amounts of $\mathrm{CHO}$, but the condition of the secreted CHO changed from a dissolved to an insoluble state in the presence of bacteria. Nonetheless, in both cases it is evident that A. minutissimum strongly secreted CHO even when no structured EPS was visible. When nutrients become limited-thus within the stationary phase-increased EPS production and capsule formation is a known phenomenon (Lewin 1955, Bhosle et al. 1995, Staats et al. 2000) and is assumed to serve also as an overflow mechanism (Staats et al. 2000).

The exact function of capsules produced by A. minutissimum is still unclear. Geitler (1977) proposed that capsule formation of this alga is involved in sexual reproduction, whereas pads and stalks are regarded as common structures of vegetative cells. This proposal was based on the observation that the capsule may engulf both mating partners, however, we also found single cells to be surrounded by a capsule. According to Lewin (1955) the production of cell bound gelatinous matter may provide attachment, which is supported by our observation that cells exhibiting capsules were attached to each other or to artificial surfaces. The cells of A. minutissimum are motile until they form capsules. These capsules can be stained with alcian blue in acetic acid, which stains anionic polysaccharides (Staats et al. 1999) that are thought to facilitate adhesion (Dade et al. 1990). However, in the xenic culture and in the co-culture with Bacteroidetes strain 32, the diatom cells within a few days adhered to the surface mediated by stalks before a capsule became visible. We therefore conclude that bacterially induced capsulation may not be a prerequisite for surface-attachment, but possibly for strengthening the attachment and for irreversible binding. Diffuse EPS, also known as transparent exopolymer particles (Passow 2002), observed both in the axenic and xenic cultures, obviously did not facilitate surface adhesion, as axenic cells can be easily removed during the washing procedures. Surface adhesion of diatoms could be relevant once the cells found a favorable environment e.g., when they recognize the presence of an interaction partner. This would implicate a mutualistic character of the interaction with Bacteroi detes strain 32. Indeed, the bacterium was not able to grow in BM alone, suggesting that exudates from the diatom are utilized as carbon sources. The finding of a clearly higher abundance of bacteria in coculture with diatoms compared with the bacterial growth in the respective diatom medium, supports 
that this is also the case for exudates from other diatom species (Grossart et al. 2006, Gärdes et al. 2010). Thus, a further explanation for capsulation in the presence of bacteria could be that the capsule itself may serve as a feeding ground for the bacteria and may help to keep the bacteria in close proximity to the diatom cell. It is tempting to speculate that bacteria may induce cell aggregation and biofilm formation of the diatom to keep the alga in spatial proximity and to ensure an adequate nutrient supply by the primary producer. The diatom in turn may benefit from the general properties of the biofilm, e.g., protection from toxic compounds (Ceri et al. 1999), UV radiation (Ehling-Schulz et al. 1997), and grazer protection. They may also directly benefit from the bacterium, for example, by bacterial supply of essential nutrients (e.g., vitamins). The medium used in this study indeed contains sufficient basic nutrients for unlimited diatom growth. However, once a biofilm is established, local nutrient deficiency may occur which may be compensated by bacteria.

Microscopic analyses revealed that the bacterial cells of the xenic culture most likely cannot penetrate the capsule, which is visible by a bacteria-free area around the diatom cell (data not shown), and thus the diatom may prevent being overgrown or parasitized by bacteria. This may be much more evident when the diatom cells are stressed and thus much more vulnerable. In this context capsulation could also represent a defense mechanism. The capsule could further protect the diatom cells from toxic bacterial compounds as EPS may reduce the susceptibility of biofilm organisms to some substances (Stewart and William Costerton 2001).

\section{CONCLUSIONS}

The bioassay for analysis of bacterial influence on biofilm structure and quantity of A. minutissimum established in this study proved to be very reliable. The enhanced biofilm formation is visible by eye after staining with crystal violet, allowing a fast screening of a large number of substances as shown here for fractions of the separated bacterial supernatant. The assay could possibly be extended to test the impact of other chemicals on the biofilm formation of this or even other diatom species. Achnanthi dium minutissimum turned out to be an excellent model organism for the investigation of biofilm formation as it produces large amounts of soluble and bound EPS and it can be cryopreserved by using a modified protocol according to Buhmann et al. (2013). The bioassay is based on the interaction of the alga with Bacteroidetes strain 32 as this bacterium induces the same physiological changes of capsulation and biofilm formation as shown for the satellite community of A. minutissimum. Up to now, little is known about the chemical interactions between diatoms and bacteria. The identification of the bioactive compound(s) of Bacteroidetes strain 32 and further physiological studies will be important to show whether the interaction between $A$. minutiss imum and Bacteroidetes strain 32 has a mutualistic or an antibiotic character.

The authors gratefully acknowledge the financial support by the Konstanz Research School Chemical Biology (KoRSCB, GSC 218) and the University of Konstanz. We also would like to thank Georg Pohnert (University of Jena) for very helpful discussions and Annette Ramsperger, Vera Bleicher, and Jo ana Thiel for technical support.

Amin, S. A., Parker, M. S. \& Armbrust, E. V. 2012. Interactions between diatoms and bacteria. Microbiol. Mol. Biol. Rev. $76: 66784$.

Bahulikar, R. A. \& Kroth, P. G. 2008. The complex extracellular polysaccharides of mainly chain forming freshwater diatom species from epilithic biofilms. J. Phycol. 44:1465 75.

Baik, K. S., Kim, M. S., Kim, E. M., Kim, H. R. \& Seong, C. N. 2007. Dyadobacter koreensis sp. nov., isolated from fresh water. Int. J. Syst. Evol. Microbiol. 57:1227 31.

Bell, W. \& Mitchell, R. 1972. Chemotactic and growth responses of marine bacteria to algal extracellular products. Biol. Bull. 143:265 77.

Bhosle, N., Sawant, S., Garg, A. \& Wagh, A. 1995. Isolation and partial chemical analysis of exopolysaccharides from the marine fouling diatom Navicula subinflata. Bot. Mar. 38: 10310.

Bruckner, C. G., Bahulikar, R., Rahalkar, M., Schink, B. \& Kroth, P. G. 2008. Bacteria associated with benthic diatoms from Lake Constance: phylogeny and influences on diatom growth and secretion of extracellular polymeric substances. Appl. Environ. Microbiol. 74:7740 9.

Buhmann, M. T., Day, J. G. \& Kroth, P. G. 2013. Post cryopreser vation viability of the benthic freshwater diatom Planothidi um frequentissimum depends on light levels. Cryobiology 67: 239.

Ceri, H., Olson, M. E., Stremick, C., Read, R. R., Morck, D. \& Buret, A. 1999. The Calgary Biofilm Device: new technology for rapid determination of antibiotic susceptibilities of bacte rial biofilms. J. Clin. Microbiol. 37:1771 6.

Chelius, M. K. \& Triplett, E. W. 2000. Dyadobacter fermentans gen. nov., sp. nov., a novel gram negative bacterium isolated from surface sterilized Zea mays stems. Int. J. Syst. Evol. Microbiol. 50:751 8 .

Chhabra, S. R., Philipp, B., Eberl, L., Givskov, M., Williams, P. \& Cámara, M. 2005. Extracellular communication in bacteria. In Schulz, S. [Ed.] The Chemistry of Pheromones and Other Semio chemicals II Topics in Current Chemistry. Springer, Berlin/ Heidelberg, pp. 279315.

Chiovitti, A., Higgins, M. J., Harper, R. E., Wetherbee, R. \& Ba cic, A. 2003. The complex polysaccharides of the raphid diatom Pinnularia viridis (Bacillariophyceae). J. Phycol. 39: 54354.

Chiovitti, A., Molinoa, P., Crawford, S. A., Teng, R., Spurcka, T. \& Wetherbee, R. 2004. The glucans extracted with warm water from diatoms are mainly derived from intracellular chrysol aminaran and not extracellular polysaccharides. Eur. J. Phy col. 39:117 28.

Cole, J. J. 1982. Interactions between bacteria and algae in aqua tic ecosystems. Annu. Rev. Ecol. Syst. 13:291 314.

Cooksey, K. \& Wigglesworth Cooksey, B. 1995. Adhesion of bacte ria and diatoms to surfaces in the sea: a review. Aquat. Mic rob. Ecol. 9:87 96.

Croft, M. T., Lawrence, A. D., Raux Deery, E., Warren, M. J. \& Smith, A. G. 2005. Algae acquire vitamin B12 through a sym biotic relationship with bacteria. Nature 438:90 3 .

Czarnecki, D. B. 1994. The freshwater diatom culture collection at Loras College, Dubuque, Iowa USA. In Kociolek, J. [Ed.] Proceedings of the 11 International Diatom Symposium, Memoirs of 
the California Academy of Sciences. California Academy of Sci ence, San Francisco, pp. 15574.

Dade, W. B., Davis, J. D., Nichols, P. D., Nowell, A. R., Thistle, D., Trexler, M. B. \& White, D. C. 1990. Effects of bacterial exo polymer adhesion on the entrainment of sand. Geomicrobiol J. $8: 116$.

De Brouwer, J. F. C. \& Stal, L. J. 2004. Does warm water extrac tion of benthic diatoms yield extracellular polymeric sub stances or does it extract intracellular chrysolaminaran? Eur. J. Phycol. 39:129 31.

De Brouwer, J. F. C., Wolfstein, K. \& Stal, L. J. 2002. Physical characterization and diel dynamics of different fractions of extracellular polysaccharides in an axenic culture of a ben thic diatom. Eur. J. Phycol. 37:37 44.

Decho, A. W. 1990. Microbial exopolymer secretions in ocean environments: their role(s) in food webs and marine pro cesses. Oceanogr. Mar. Biol. Annu. Rev. 28:73 153.

Dubois, M., Gilles, K. A., Hamilton, J. K., Rebers, P. A. \& Smith, F. 1956. Colorimetric method for determination of sugars and related substances. Anal. Chem. 28:350 6.

Ehling Schulz, M., Bilger, W. \& Scherer, S. 1997. UV B induced synthesis of photoprotective pigments and extracellular poly saccharides in the terrestrial cyanobacterium Nostoc commune. J. Bacteriol. 179:1940 5.

Fowler, S. W. \& Knauer, G. A. 1986. Role of large particles in the transport of elements and organic compounds through the oceanic water column. Progr. Oceanogr. 16:147 94.

Gardes, A., Iversen, M. H., Grossart, H. P., Passow, U. \& Ullrich, M. S. 2010. Diatom associated bacteria are required for aggregation of Thalassiosira weissflogii. ISME 5:436 45.

Gawne, B., Wang, Y., Hoagland, K. D. \& Gretz, M. R. 1998. Role of bacteria and bacterial exopolymer in the attachment of Achnanthes longipes (Bacillariophyceae). Biofouling 13:137 56.

Gaylarde, C. C. \& Morton, L. G. 1999. Deteriogenic biofilms on buildings and their control: a review. Biofouling 14:59 74.

Geitler, L. 1977. Entwicklungsgeschichtliche Eigentumlichkeiten einiger Achnanthes Arten (Diatomeae). Plant Syst. Evol. 126:37792.

Grossart, H. P., Czub, G. \& Simon, M. 2006. Algae bacteria inter actions and their effects on aggregation and organic matter flux in the sea. Environ. Microbiol. 8:1074 84.

Hoagland, K. D. \& Peterson, C. G. 1990. Effects of light and wave disturbance on vertical zonation of attached microalgae in a large reservoir. J. Phycol. 26:450 7.

Hoagland, K. D., Rosowski, J. R., Gretz, M. R. \& Roemer, S. C. 1993. Diatom extracellular polymeric substances: function, fine structure, chemistry, and physiology. J. Phycol. 29:537 66.

Izano, E. A., Wang, H., Ragunath, C., Ramasubbu, N. \& Kaplan, J. B. 2007. Detachment and killing of Aggregatibacter actinomy cetemcomitans biofilms by dispersin B and SDS. J. Dent. Res. 86:618 22.

Jagmann, N., Brachvogel, H. P. \& Philipp, B. 2010. Parasitic growth of Pseudomonas aeruginosa in co culture with the chitinolytic bacterium Aeromonas hydrophila. Environ. Microbiol. 12:1787 802 .

Jeffrey, S. W. \& Humphrey, G. F. 1975. New spectrophotometric equations for determining chlorophylls $a, b, c 1$ and $c 2$ in higher plants, algae and natural phytoplankton. Biochem. Physiol. Pfl. 167:191 4.

Joint, I., Tait, K. \& Wheeler, G. 2007. Cross kingdom signalling: exploitation of bacterial quorum sensing molecules by the green seaweed Ulva. Philos. Trans. R. Soc. Lond. B 362: 122333.

Kaplan, J. B. \& Fine, D. H. 2002. Biofilm dispersal of Neisseria subflava and other phylogenetically diverse oral bacteria. Appl. Environ. Microbiol. 68:4943 50.

Knoll, S., Zwisler, W. \& Simon, M. 2001. Bacterial colonization of early stages of limnetic diatom microaggregates. Aquat. Mic rob. Ecol. 25:141 50 .

Kobayashi, K., Takata, Y. \& Kodama, M. 2009. Direct contact between Pseudo nitzschia multiseries and bacteria is necessary for the diatom to produce a high level of domoic acid. Fish. Sci. 75:771 6.

Krammer, K. \& Lange Bertalot, H. 1991. Sußwasserflora von Mitte leuropa, Bacillariophyceae. Achnanthaceae. Kritische Erganzungen zu Navicula (Lineolatae) und Gomphonema. Gustav Fischer Ver lag, Stuttgart.

Lewin, J. C. 1955. The capsule of the diatom Navicula pelliculosa. J. Gen. Microbiol. 13:1629.

Mieszkin, S., Martin Tanchereau, P., Callow, M. E. \& Callow, J. A. 2012. Effect of bacterial biofilms formed on fouling release coatings from natural seawater and Cobetia marina, on the adhesion of two marine algae. Biofouling 28:953 68 .

Miller, J. H. 1972. Experiments in Molecular Genetics. Cold Spring Harbor Laboratory Cold Spring Harbor, New York, 466 pp.

Myklestad, S., Holm Hansen, O., Vårum, K. M. \& Volcani, B. E. 1989. Rate of release of extracellular amino acids and carbo hydrates from the marine diatom Chaetoceros affinis. J. Plank ton Res. 11:763 73 .

Passow, U. 2002. Transparent exopolymer particles (TEP) in aquatic environments. Prog. Oceanogr. 55:287 333.

Patrick, R. \& Reimer, C. W. 1966. The Diatoms of the United States Academy of Natural Sciences of Philadelphia, Philadelphia, 688 pp.

Rao, T. 2010. Comparative effect of temperature on biofilm for mation in natural and modified marine environment. Aquat. Ecol. 44:463 78 .

Sapp, M., Wichels, A., Wiltshire, K. H. \& Gerdts, G. 2007. Bacte rial community dynamics during the winter spring transition in the North Sea. FEMS Microbiol. Ecol. 59:622 37.

Schmieder, K., Dienst, M., Ostendorp, W. \& Johnk, K. 2004. Effects of water level variations on the dynamics of the reed belts of Lake Constance. Int. J. Ecohydrol. Hydrobiol. 4:469 80.

Schultz, M., Bendick, J., Holm, E. \& Hertel, W. 2011. Economic impact of biofouling on a naval surface ship. Biofouling 27:87 98

Sekar, R., Venugopalan, V. P., Nandakumar, K., Nair, K. V. K. \& Rao, V. N. R. 2004. Early stages of biofilm succession in a lentic freshwater environment. Hydrobiologia 512:97 108.

Staats, N., De Winder, B., Stal, L. J. \& Mur, L. R. 1999. Isolation and characterization of extracellular polysaccharides from the epipelic diatoms Cylindrotheca closterium and Navicula sali narum. Eur. J. Phycol. 34:161 9.

Staats, N., Stal, L. J. \& Mur, L. R. 2000. Exopolysaccharide pro duction by the epipelic diatom Cylindrotheca closterium: effects of nutrient conditions. J. Exp. Mar. Biol. Ecol. 249:13 27.

Stanish, L. F., O’Neill, S. P., Gonzalez, A., Legg, T. M., Knelman, J., McKnight, D. M., Spaulding, S. \& Nemergut, D. R. 2012. Bacteria and diatom co occurrence patterns in microbial mats from polar desert streams. Environ. Microbiol. 15:1115 31.

Stewart, P. S. \& William Costerton, J. 2001. Antibiotic resistance of bacteria in biofilms. The Lancet 358:135 8 .

Thomas, T. E. \& Robinson, M. G. 1987. The role of bacteria in the metal tolerance of the fouling diatom Amphora coffeaefor mis Ag. J. Exp. Mar. Biol. Ecol. 107:291 7.

Von Elert, E. \& Pohnert, G. 2000. Predator specificity of kairo mones in diel vertical migration of Daphnia: a chemical approach. Oikos 88:119 28 .

Wetherbee, R., Lind, J. L., Burke, J. \& Quatrano, R. S. 1998. Mini review The first kiss: establishment and control of initial adhesion by raphid diatoms. J. Phycol. 34:9 15.

Wetzel, R. G. 1964. A comparative study of the primary produc tion of higher aquatic plants, periphyton, and phytoplankton in a large, shallow lake. Internationale Revue der gesamten $H y$ drobiologie und Hydrographie 49:1 61.

Wigglesworth Cooksey, B., Berglund, D. \& Cooksey, K. E. 2001. Cell cell and cell surface interactions in an illuminated bio film: implications for marine sediment stabilization. Geochem. Trans. 10:75 82.

Windler, M., Gruber, A. \& Kroth, P. G. 2012. Purification of ben thic diatoms from associated bacteria using the antibiotic im ipenem. J. Endocytobiosis Cell Res. 22:62 5. 
Wingender, J. \& Flemming, H. C. 2011. Biofilms in drinking water and their role as reservoir for pathogens. Int. J. Hyg. Environ. Health 214:417 23.

Wustman, B. A., Gretz, M. R. \& Hoagland, K. D. 1997. Extracellular matrix assembly in diatoms (Bacillariophyceae) (I. A model of adhesives based on chemical characterization and localization of polysaccharides from the marine diatom Achnanthes longipes and other diatoms). Plan. Physiol. 113:1059 69.

Zhang, D. C., Liu, H. C., Xin, Y. H., Zhou, Y. G., Schinner, F. \& Margesin, R. 2010. Dyadobacter psychrophilus sp. nov., a psy chrophilic bacterium isolated from soil. Int. J. Syst. Evol. Microbiol. 60:1640 3 .

\section{Supporting Information}

Additional Supporting Information may be found in the online version of this article at the publisher's web site:

Appendix S1. Description of methods applied to generate data shown in the supporting information.

Figure S1. Standard curves of several carbohydrates prevalent in A. minutissimum $(n=1)$.
Figure S2. Comparison of glucose and glucuonic acid standard curves in Phenol-sulfuric acid ssay $(n=1)$.

Figure S3. Growth of Bacteroidetes strain 32 in iatom full medium (BM). The bacterium was ultivated in BM medium $(n=2)$ and in diluted B $(n=1)$.

Figure S4. Quantification of carbohydrates and microscopic images of the xenic and axenic A. minutissimum cells in different extracts.

Figure S5. Absorption of crystal violet extracted rom biofilms of co-cultures of A. minutissimum with different bacterial isolates.

Figure S6. Quantification of carbohydrate elease from cells during defatting steps with $\mathrm{tOH}(n=1)$.

Figure S7. Quantification of chlorophyll residue n defatted pellet $(n=1)$. 